\title{
Mnenje študentov kineziologije o pomenu študijskih in obštudijskih vsebin za prehod $v$ delovno okolje
}

\author{
Matej Plevnik \\ Univerza na Primorskem \\ matej.plevnik@fvz.upr.si
}

\begin{abstract}
Skrb za uspešen prehod diplomantov $v$ delovno okolje sodi med naloge izvajalcev študijskih programov. Z vprašalnikom smo med 78 študenti dodiplomskega programa Aplikativna kineziologija (UP FVZ) preverjali mnenje o pomenu študijskih oblik in dopolnitvenih aktivnosti za prehod $v$ delovno okolje. Izračunali smo opisno statistiko in analizirali dimenzionalno strukturo. Študentje kot najpomembnejšo ocenjujejo trditev »poznavanja in usvojenosti vsebin obveznih predmetov s področno strokovnimi vsebinami $(A S=4,68, S O=0,55)$, kot najpomembnejši faktor pa »dopolnilne študijske vsebine« $(A S=4,36, S O=$ 0,66). Največji delež variance $(37,27 \%)$ pojasni faktor »vseživljenjsko učenje«. Študentje največji interes za umestitev po zaključku študija izražajo za področja rekreativnega športa $(A S=4,08 ; S O=0,81)$, krepitve zdravja $(A S=4,0$; $S O=1,09)$ in vrhunskega športa $(A S=3,88 ; S O=1,41)$. Rezultati kažejo mnenje študentov o različnih študijskih in obštudijskih vsebinah za uspešen prehod $v$ delovno okolje.
\end{abstract}

Ključne besede: delovno okolje, kineziolog, vadba, šport, zdravje

\section{Uvod}

Področje kineziologije je izrazito interdisciplinarno (Zelaznik in Harper 2007; Bodary in Gross 2018; Ennis 2010; Melton, Hansen in Gross 2010), njegova temeljna vsebina pa je preučevanje gibalne aktivnosti ter študij učinkov gibalne aktivnosti in vadbe/treninga na človeka (Prskalo, Badrić in Tomić 2019). Redna gibalna aktivnost sodi med ključne dejavnike varovanja in krepitve zdravja, ki prispeva k boljšemu zdravju in večji kakovosti življenja (Gill idr. 2013; Piercy idr. 2018; Hallal idr. 2012; MacCallum, Howson in Gopu 2012; World Health Organization 2018). Med odraščanjem redna gibalna aktivnost vpliva na optimalno telesno rast in razvoj, izboljšuje splošno počutje in delovno storilnost pri odraslih, dolgoročno pa predvsem vpliva na krepitev zdravja, povečuje kakovost življenja in prispeva k aktivnemu ter zdravemu staranju (Resolucija o nacionalnem programu o prehrani in telesni dejavnosti za zdravje 2015-2025 2015). Ohranjanje gibalnih navad ter aktivnega in zdravega načina 
življenja v odraslosti predstavlja, zaradi vse hitrejšega načina življenja, poseben izziv za aktivni del populacije (Bauman idr. 2012; Warburton in Bredin 2017).

Področje gibalne/športne aktivnosti in strokovno delo v športu je v Sloveniji opredeljeno v več nacionalnih dokumentih: Zakonu o športu (2017), Resoluciji o nacionalnem programu športa za obdobje 2013-2024 (2014) in Resoluciji o nacionalnem programu o prehrani in telesni dejavnosti za zdravje (2015) ter podrejenih pravilnikih in aktih. Opredelitve področja pomembno vplivajo na možnosti umeščanja diplomantov kineziologije $v$ delovno okolje, tako z vidika izvajanja vsebine kot z vidika sistemske umeščenosti poklica v področja dela družbe. Zakon o športu (2017) v 46. členu navaja, da lahko strokovno delo $v$ športu izvaja strokovni delavec, ki ima ustrezno izobrazbo ali usposobljenost skladno $z$ zakonom in je vpisan v razvid strokovno izobraženih ter strokovno usposobljenih delavcev v športu. Strokovno izobražen delavec, ki ima izobrazbo, pridobljeno po javnoveljavnem študijskem programu prve ali druge stopnje, lahko v skladu s pridobljenimi kompetencami načrtuje, organizira, izvaja, spremlja in vrednoti proces športne vadbe. Zakon o športu v 6. členu navaja devet programov športa, ki predstavljajo pojavne oblike športa, namenjene posameznikom vseh starosti, to so (1) prostočasna športna vzgoja otrok in mladine, (2) športna vzgoja otrok in mladostnikov s posebnimi potrebami, (3) obštudijska športna dejavnost, (4) športna vzgoja otrok in mladine, usmerjenih v kakovostni in vrhunski šport, (5) kakovostni šport, (6) vrhunski šport, (7) šport invalidov, (8) športna rekreacija in (9) šport starejših.

Resolucija o nacionalnem programu športa v Republiki Sloveniji 2014-2023 (2014) na podlagi Zakona o športu opredeljuje javni interes, ki ga udejanjajo nosilci in izvajalci slovenskega športa. $Z$ navedenim dokumentom država soustvarja pogoje za razvoj športa kot pomembnega dejavnika razvoja posameznika in družbe ter prispeva $\mathrm{k}$ zmanjševanju neenakosti na področju dostopnosti do športne vadbe. Šport je temeljna pravica vsakega človeka, tako otroka, mladostnika in odraslega človeka kot starostnika, znotraj teh skupin pa tudi vseh oseb s posebnimi potrebami. Športna dejavnost je pomembna za blaginjo prebivalcev Republike Slovenije. Zaradi vpliva na razvoj mladega človeka in s tem tesno povezanega oblikovanja zdravega življenjskega sloga ter pridobivanja socialnih kompetenc predstavlja športna dejavnost otrok in mladine prednostno vsebino nacionalnega programa športa, prav tako pa je izjemnega pomena redna športno-rekreativna dejavnost odraslih. Družbena vloga športa izhaja iz znanstveno dokazanega pomena športa za javno zdravje (telesno, duševno in socialno), socializacijo in gospodarstvo. Splet 
družbenih vlog pomeni prepletenost športa z različnimi družbenimi področji: zdravstvom, vzgojo in izobraževanjem, gospodarstvom, okoljem, turizmom, kulturo, financami, prometom idr. Kakovostni strokovni kadri v športu so ključ njegovega razvoja in uspešnosti. Najvišjo strokovno raven predstavlja strokovno izobražen kader, ki zaključi univerzitetni ali visokošolski študijski program s področja športa (kineziologije). Ukrep NPŠ 2013-2024 je med drugim tudi izboljšati kompetence strokovnega kadra, ki organizira in izpeljuje gibalne/športne programe.

Namen Resolucije o nacionalnem programu o prehrani in telesni dejavnosti za zdravje 2015-2025 (2015) je izboljšati prehranske in gibalne navade prebivalcev od zgodnjega obdobja življenja do pozne starosti. Tako želi Republika Slovenija zaustaviti in obrniti trend naraščanja telesne mase prebivalcev in vplivati na manjšo pojavnost kroničnih nenalezljivih bolezni (KNB) ter posledično na vzdržnost zdravstvenega sistema. S predvidenimi ukrepi se želi vplivati tudi na enake možnosti za zdravje za vse prebivalce, tudi za socialno in ekonomsko ogrožene skupine, ter ugodno vplivati na bio-psihosocialni razvoj vsakega posameznika. Omenjena resolucija strokovni profil kineziologa omenja tudi samostojno, ne zgolj kot enega izmed profilov strokovnega delavca v športu, in sicer na področju telesne dejavnosti ( $v$ nadaljevanju zaradi poenotenja strokovne terminologije gibalne aktivnosti) za krepitev zdravja v programih gibalnih aktivnosti starejših odraslih, programih ugotavljanja primanjkljaja $v$ telesni pripravljenosti posameznikov $v$ okviru interdisciplinarnih svetovalnic za telesni in gibalni razvoj v zdravstvenih domovih, pri delu s starostnimi skupinami otrok in mladostnikov ter odraslih prebivalcev s poudarkom na posebnih potrebah starejših. Izredno pomembno vlogo pri umeščanju diplomanta kineziologije resolucija predstavlja s ciljem preučitve uspešnosti uvedbe novega profila strokovnjaka $z$ vidika telesne pripravljenosti na vseh treh ravneh zdravstvenega in socialnega varstva, $v$ zdravstvenih ustanovah in socialnovarstvenih zavodih. $\mathrm{S}$ tem je bila postavljena podlaga za umeščanje profila kineziologa na omenjeno področje, najprej v okviru projektnega sodelovanja, npr. projekt »Skupaj za zdravje« (Nacionalni inštitut za javno zdravje 2016; Jakovljević, Knific in Petrič 2017), ter kasneje kot člana interdisciplinarnega tima centrov za krepitev zdravja v okviru primarne zdravstvene mreže (Nacionalni inštitut za javno zdravje 2020).

Kot profil strokovnjaka so kineziologi z rezultati dela pomembno prispevali k skupnim rezultatom interdisciplinarnega tima strokovnjakov (Strel idr. 2016; Backović Juričan 2020), zato se nadaljujejo prizadevanja za umestitev kineziologa v seznam zdravstvenih sodelavcev v okviru Seznama poklicev v zdravstveni dejavnosti (Resolucija o nacionalnem programu športa $v$ Repu- 
bliki Sloveniji za obdobje 2014-2023 2014), kar bi pomenilo sistemsko umestitev profila kineziologa na področje zdravstva. Diplomirani kineziologi v okviru izobraževanja pridobijo tudi ustrezne kompetence s področij ergonomije, zdravstvene preventive ter ohranjanja in promocije zdravja, s katerimi lahko izvajajo promocijo zdravja na delovnem mestu. Slednjo so delodajalci za zaposlene dolžni izvajati skladno z Zakonom o varstvu in zdravju pri delu (2011).

Aktivnosti umeščanja kineziologov $v$ delovna okolja so postale intenzivnejše hkrati z zaključkom študija prvih generacij vpisanih študentov v študijski program (Plevnik in Pišot 2016; Kleva 2017). Sistematičnih raziskav, ki poročajo o zaposlitvah kineziologov, nismo zasledili. Ena zadnjih študij (Plevnik in Babnik 2020), ki poroča o željah študentov kineziologije za umestitev v delovna področja, pa ugotavlja, da so študentje največji interes izkazali za delo na področjih rekreativnega športa, vrhunskega športa ter krepitve zdravja. Izkazan interes predstavlja ujemanje $z$ nacionalnimi smernicami in priporočili za umeščanje strokovnega kadra s področja športa ter kineziologov na področji vodenja programov športa ter programov gibalnih/športnih aktivnosti za krepitev zdravja.

Kineziologija kot znanstvena disciplina ima dolgo zgodovino in tradicijo, kot strokovno področje pa se je razvila šele v zadnjem desetletju. $V$ Sloveniji se dodiplomski študijski program Kineziologija izvaja na dveh fakultetah (na Univerzi na Primorskem, Fakulteti za vede o zdravju (UP FVZ) od leta 2010 dalje in na Univerzi v Ljubljani, Fakulteti za šport od leta 2009 dalje). Osrednje področje kineziologije je preučevanje gibalnih/športnih aktivnosti človeka, skozi prizmo razvoja telesnih značilnosti ter gibalnih sposobnosti in spretnosti je tesno povezana s področji krepitve zdravja ter vseh pojavnih oblik športa (Hoffman in Knudson 2018, 28; Prskalo, Badrić in Tomić 2019). Diplomirani/-a kineziolog/-inja, diplomant/-ka študijskega programa aplikativna kineziologija, je strokovni delavec $v$ športu, skladno $z$ odločbo št. 6037/2/2018/6, ki jo je izdal Direktorat za šport pri Ministrstvu za izobraževanje, znanost in šport in s katero je javnoveljavni univerzitetni študijski program prve stopnje Aplikativna kineziologija, ki ga izvaja Fakulteta za vede o zdravju Univerze na Primorskem, uvrščen na seznam javnoveljavnih študijskih programov, ki dajejo kompetence za strokovno izobraženega delavca v športu (Fakulteta za vede o zdravju b. I.).

\section{Opredelitev namena in ciljev prispevka}

Namen prispevka je opisati pomen študijskih oblik in vsebin za bodoče poklicno delo kineziologov ter opredeliti možnosti umeščanja vsebin kinezio- 
logije $v$ delovna okolja. Skladno z namenom smo postavili dva cilja, in sicer (i) predstaviti, kako študentje kineziologije opredeljujejo pomen posameznih študijskih oblik, vsebin in dopolnitvenih študijskih aktivnosti za prehod $v$ delovno okolje po zaključku študija, ter (ii) ugotoviti, katera delovna okolja in področja dela študentje kineziologije opredeljujejo kot najbolj zaželena. S pridobitvijo mnenja študentov želimo ovrednotiti študijske vsebine, ki jim študentje pripisujejo največji pomen za prehod v delovno okolje.

\section{MetodE}

\section{Vzorec}

Vzorec je sestavljen iz 72 redno in šestih izredno vpisanih študentov (skupaj $n=78$ ) dodiplomskega študijskega programa Aplikativna kineziologija (UP FVZ), ki so se odzvali povabilu za vključitev v študijo in ustrezno rešili spletni vprašalnik. Glede na vpis študentov v nadaljevanju nismo ločevali. Značilnosti vzorca so prikazane $v$ preglednici 1.

Skladno z namenom raziskave nas je zanimalo stanje obstoječih delovnih izkušenj študentov, ki so predstavljali vzorec anketirancev. Študentje so glede na stanje svojih delovnih izkušenj navedli, da jih 8,1\% nima še nikakršnih delovnih izkušenj, 48,1\% ima delovne izkušnje, vendar ne na strokovnem področju kineziologije/športa, 43,2 \% pa že ima delovne izkušnje na tem področju kineziologije/športa. Statistično značilnih razlik med študenti različnih letnikov študija in njihovimi delovnimi izkušnjami nismo ugotovili. Navedbo študentov o obstoječih delovnih izkušnjah smo v nadaljevanju uporabili kot eno izmed spremenljivk v nadaljnjih statističnih analizah.

\section{Pripomočki in postopek zbiranja podatkov}

V okviru študije smo pripravili spletni vprašalnik, ki je vseboval (i) splošne podatke o anketirancih, (ii) 19 postavk o pomenu študijskih oblik in vsebin

Preglednica 1 Značilnosti vzorca

\begin{tabular}{|c|c|c|c|c|c|c|c|c|c|}
\hline \multirow[t]{2}{*}{ Letnik } & \multicolumn{3}{|c|}{ Moški } & \multicolumn{3}{|c|}{ Ženske } & \multicolumn{3}{|c|}{ Skupaj } \\
\hline & (1) & (2) & (3) & (1) & (2) & (3) & (1) & (2) & (3) \\
\hline 1. letnik & 5 & 19,80 & 0,84 & 13 & 19,85 & 0,99 & 18 & 19,81 & 0,92 \\
\hline 2. letnik & 5 & 20,80 & 1,30 & 18 & 20,56 & 0,92 & 23 & 20,61 & 0,98 \\
\hline 3. letnik & 6 & 21,33 & 0,52 & 24 & 22,33 & 3,20 & 30 & 22,13 & 2,88 \\
\hline Absolvent & 2 & 22,00 & 0,00 & 5 & 23,0 & 0,71 & 7 & 21,71 & 0,76 \\
\hline Skupaj & 18 & 21,64 & 1,12 & 60 & 21,42 & 0,67 & 78 & 21,21 & 2,18 \\
\hline
\end{tabular}

Opombe (1) število, (2) starost (aritmetična sredina), (3) standardni odklon. 
za uspešen prehod $v$ delovno okolje ter (iii) ocene želja za umestitev v specifično področje delovnega okolja. Študentje so izražali svoja stališča na podlagi petstopenjske Likertove lestvice. Vabilo za sodelovanje s povezavo do vprašalnika smo preko e-pošte poslali vsem študentom dodiplomskega programa Aplikativna kineziologija (UP FVZ) ( $n=200$; prvi letnik $n=61$, drugi letnik $n=56$, tretji letnik $n=51$ in absolvent $n=32$ ), ki so bili v marcu 2021 prvič ali ponovno vpisani v letnik študija. Stopnja odziva je bila $39 \%$.

\section{Analiza podatkov}

Podatke smo iz spletnega portala 1ka izvozili v program MS Excel (Microsoft Office), kjer smo jih ustrezno uredili. Za statistično analizo podatkov smo v nadaljevanju uporabili program IBM SPSS Statistics 26. Uporabili smo opisno statistiko (frekvence, aritmetična sredine, standardni odklon). Izračunali smo zanesljivost vprašalnika s statističnim preizkusom Cronbachova alfa $(\alpha)$ in analizirali dimenzionalno strukturo $s$ faktorsko analizo, metodo glavnih komponent s pravokotno (varimax) rotacijo. Za analizo razlik smo uporabili $\chi^{2}$-statistični preizkus hipoteze neodvisnosti in Kruskal-Wallisov $\mathrm{H}$-statistični preizkus. Statistično značilnost smo ugotavljali s 5-odstotno ravnjo statističnega tveganja $(p<0.05)$.

\section{Rezultati in razprava}

Namen študije je bil preveriti mnenje študentov dodiplomskega študija kineziologije o pomenu različnih študijskih oblik in vsebin za uspešen prehod $v$ delovno okolje. Za rezultate ocen devetnajstih trditev smo opravili opisno statistiko (preglednica 2 ) in preverili predpostavke za izvedbo statističnega preizkusa faktorske analize. Izločili smo tri trditve. Metoda faktorske analize (metoda glavnih komponent, rotacija varimax) je izločila štiri faktorje z lastno vrednostjo več kot ena, ki skupaj pojasnijo $66,42 \%$ variance v odgovorih udeležencev (preglednica 3). Vrednost Kaiser-Meyer-Olkinovega preizkusa (KMO) je znašala o,772, kar potrjuje vrednost vzorčenja, saj je KMO višja od priporočene (vsaj o,60). Bartlettov preizkus sferičnosti je pokazal, da je povezanost med spremenljivkami dovolj visoka $(p<0,001)$ in so zato podatki primerni za faktorsko analizo. Na podlagi izračuna komunalitet (deleža variance postavk, ki je pojasnjen s skupnimi faktorji) smo ugotovili, da nobena od komunalitet ni nižja od priporočene vrednosti 0,20 (Child 2006), zato smo izbrane postavke/trditve vključili v nadaljnji postopek faktorske analize.

Študentje med vsemi posamičnimi postavkami najvišje ocenjujejo pomen (2.) poznavanja in usvojenosti vsebin obveznih predmetov s področno strokovnimi vsebinami $(A S=4,68, S O=0,553)$, (19.) razvoja osebnih značilnosti 
Preglednica 2 Opisna statistika (AS; SO) za vprašalnik pomena študijskih oblik in vsebin za uspešen prehod v delovno okolje, kot jih ocenjujejo dodiplomski študentje kineziologije

\begin{tabular}{|c|c|c|c|}
\hline \multicolumn{2}{|r|}{ Študijske oblike in vsebine } & \multirow{2}{*}{$\frac{A S}{3.16}$} & \multirow{2}{*}{$\frac{\text { SO }}{1.0379}$} \\
\hline 16 & $\begin{array}{l}\text { Udeležba v delanicah Kariernega centra (npr. podjetniško sodelova- } \\
\text { nje...) }\end{array}$ & & \\
\hline 8 & Dobra priprava na teoretične izpite in pridobivanje visokih ocen izpitov & 3.32 & 567 \\
\hline 17 & $\begin{array}{l}\text { Publicistična dejavnost med študijem (npr. pisanje strokovnih člankov } \\
\text { za revije, spletne strani...) }\end{array}$ & 3.39 & 4 \\
\hline 11 & $\begin{array}{l}\text { Sodelovanje pri študentskih projektih (npr. v okviru študentske organi- } \\
\text { zacije) }\end{array}$ & 3.43 & 1.0776 \\
\hline 9 & Dobra priprava praktičnih izdelkov (npr. seminarske naloge) & 3.48 & 1.1062 \\
\hline 15 & Udeležba v oblikah mednarodne mobilnosti & 3.55 & 1.1316 \\
\hline 13 & Udeležba I & 3.67 & 1.0242 \\
\hline 18 & the & 3.74 & 1.133 \\
\hline 4 & pr. projekti Po krea- & 3.81 & 1.00 \\
\hline 10 & Dobra p & 4.06 & 0.9835 \\
\hline 3 & $\begin{array}{l}\text { Predm } \\
\text { nike it }\end{array}$ & 4.09 & 0.8868 \\
\hline 5 & Izbor in in dobro sodelovanje z mentorjem pri pripravi zaključnega dela & 4.20 & 0.9006 \\
\hline 6 & $\begin{array}{l}\text { Pridobivan } \\
\text { znih strokc }\end{array}$ & 4.26 & 1.0383 \\
\hline 1 & Obvezni prec & 4.36 & 0.8397 \\
\hline 14 & Pridobitev $s$ & 4.42 & 0.8813 \\
\hline 12 & odročja med poletnimi & 4.45 & 0.8666 \\
\hline 7 & 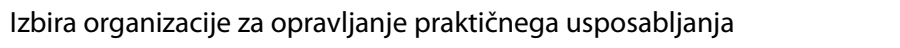 & 4.46 & 0.7392 \\
\hline 19 & Razvoj osebnih značilnosti in prednosti (samozavest, urejenost itd.) & 4.46 & 0.7392 \\
\hline 2 & nimi vsebinami (npr. osnovna mo- & 4.68 & o. \\
\hline
\end{tabular}

in prednosti $(A S=4,47, S O=0,737)$ in (7.) izbire organizacije za opravljanje obveznega praktičnega usposabljanja med študijem $(A S=4,47, S O=0,737)$. Najnižjo oceno med posamičnimi postavkami pripisujejo postavki (16.) udeležba na delavnicah Kariernega centra $(A S=3,16, S O=1,038$ ) (preglednica 2). $V$ nadaljevanju predstavljamo dimenzionalno strukturo vprašalnika (preglednica 3).

Prvi faktor smo poimenovali »vseživljenjsko učenje« in vključuje trditve, ki označujejo pomen vključenosti v aktivnosti vseživljenjskega učenja. Zaneslji- 
Preglednica 3 Dimenzionalna struktura za vprašalnik mnenja študentov dodiplomskega programa kineziologije o pomenu študijskih oblik in vsebin za uspešen prehod $v$ delovno okolje

\begin{tabular}{|c|c|c|c|c|}
\hline \multirow[t]{2}{*}{ Vsebine } & \multicolumn{4}{|c|}{ Faktorji } \\
\hline & (1) & (2) & (3) & (4) \\
\hline 15. & 0,812 & & & \\
\hline 16. & 0,798 & & & \\
\hline 13. & 0,719 & & & \\
\hline 11. & 0,515 & & & \\
\hline 4. & 0,491 & & & \\
\hline 7. & & 0,827 & & \\
\hline 12. & & 0,753 & & \\
\hline 6. & & 0,739 & & \\
\hline 14. & & 0,577 & & \\
\hline 5. & & 0,513 & & \\
\hline 19. & & & 0,804 & \\
\hline 18. & & & 0,785 & \\
\hline 17. & & & 0,604 & \\
\hline 9. & & & & 0,814 \\
\hline 8. & & & & 0,731 \\
\hline 10. & & & & 0,717 \\
\hline$\lambda$ & 5,964 & 1,992 & 1,511 & 1,163 \\
\hline Delež pojasnjene variance faktorja & 37,27 & 12,44 & 9,44 & 7,27 \\
\hline$\alpha$ & 0,838 & 0,787 & 0,776 & 0,708 \\
\hline $\mathrm{AS} \pm \mathrm{SO}$ & $3,52 \pm 0,82$ & $4,36 \pm 0,66$ & $3,88 \pm 0,85$ & $3,64 \pm 0,87$ \\
\hline Min & 1,0 & 1,8 & 1,67 & 1,67 \\
\hline Max & 5,0 & 5,0 & 5,0 & 5,0 \\
\hline
\end{tabular}

Opombe Faktorji: (1) vseživljenjsko učenje (2) dopolnilne študijske vsebine (3) komunikacijske veščine (4) priprava strokovnih študijskih izdelkov. $\lambda$ - lastna vrednost faktorja, $\alpha$ - koeficient faktorja Cronbachova alfa, AS \pm SO - aritmetična sredina \pm standardni odklon, Min najmanjša vrednost, Max - največja vrednost. Dejavnik obstoječe delovne izkušnje: $H=6,660, p$ $=0,036$. Dejavnik letnik študija: $H=12,386, p=0,002$.

vost dimenzije je ustrezna ( $\alpha=0,838)$. Drugi faktor, »dopolnilne študijske vsebine«, vključuje trditve, ki se nanašajo na pridobivanje dodatnih strokovnih znanj v okviru študijskega področja, faktor kaže sprejemljivo zanesljivost ( $\alpha$ $=0,787$ ). Tretji faktor smo poimenovali »komunikacijske veščine« in vključuje trditve, ki se nanašajo na osebni razvoj študenta ter na razvoj komunikacijskih veščin, faktor ima sprejemljivo zanesljivost $(\alpha=0,776)$. Četrti faktor smo poimenovali »priprava strokovnih študijskih izdelkov«; vključuje trditve, ki se nanašajo na pripravo kvalitetnih študijskih izdelkov ter pridobivanje visokih 
ocen izdelkov/izpitov. Tudi zanesljivost četrtega faktorja je sprejemljiva ( $\alpha=$ 0,708 ). Iz prvotnega nabora trditev smo izločili tri trditve, ki niso zagotavljale ustrezne dimenzionalne strukture vprašalnika. Izločene trditve se nanašajo na pomen vsebin predmetnika, to je pomen obveznih temeljnih predmetov, obveznih strokovnih predmetov in izbirnih predmetov. Vsebina predmetnika je dejavnik pri odločanju za vpis na študijski program, na kar pa študentje za razliko od ostalih oblikovanih predpostavk dejansko nimajo vpliva. Najvišje ocenjena dimenzija (faktor) je »dopolnilne študijske vsebine« $(A S=4,36$, SO $=0,66)$, najnižje ocenjena pa »vseživljenjsko učenje« $(A S=3,52, S O=0,82)$.

$\mathrm{S}$ Kruskal-Wallisovim $\mathrm{H}$-statističnim preizkusom smo preverili razlike med skupinami študentov z različnimi obstoječimi delovnimi izkušnjami in oceno posameznega faktorja dimenzionalne strukture vprašalnika. Ugotovili smo, da se študentje glede na obstoječe delovne izkušnje statistično značilno razlikujejo le v oceni prvega faktorja, "vseživljenjsko učenje» $(H=6,660, p=$ $0,036)$, in sicer ga skupina študentov brez delovnih izkušenj vrednoti statistično značilno najvišje (srednja vrednost rangov: skupina brez delovnih izkušenj = 51,225; skupina $z$ delovnimi izkušnjami, vendar ne na strokovnem področju $=37,09$; skupina $z$ delovnimi izkušnjami na strokovnem področju = 29,45). Ker je anketiranje potekalo med obdobjem ukrepov proti širjenju epidemije covida-19, ki so veljali v marcu 2021, nas je zanimala samoocena njihove gibalne aktivnosti. $V$ nadaljevanju smo jo upoštevali kot morebitni dejavnik za razlikovanje ocene posameznih faktorjev. Ugotavljamo, da je 15,4\% študentov tedensko gibalno aktivnost ocenilo kot nizko (gibalna aktivnost največ dvakrat tedensko do 30 minut), $74,4 \%$ študentov kot srednjo (gibalna aktivnost tri- do petkrat tedensko) in 10,3\% kot visoko (redna gibalna aktivnost več kot petkrat tedensko, tudi organizirana). Glede na stopnjo gibalne aktivnosti se študentje $v$ oceni posameznih faktorjev niso značilno razlikovali. Glede na letnik študija se študentje statistično značilno razlikujejo le v oceni faktorja »vseživljenjsko učenje« $(H=12,386, p=0,002)$, $\mathrm{z}$ rezultati srednje vrednosti rangov 41,19 za prvi, 36,11 za drugi in 22,63 za tretji letnik.

$\checkmark$ nadaljevanju nas je zanimala želja študentov po vključitvi v delovno okolje po zaključenem dodiplomskem študiju kineziologije. Za ta namen smo uporabili vprašalnik, ki opisuje osem vsebinskih področij delovnih okolij, ki predstavljajo nabor trenutnih možnosti za poklicno udejstvovanje kineziologov v Republiki Sloveniji (Plevnik in Babnik 2020): (A) krepitev zdravja; (B) organiziranost in administracija $v$ športu; (C) obšolske in prostočasne dejavnosti v vzgoji in izobraževanju; (Č) varovanje zdravja na delovnem mestu; (D) rekreativni šport; $(E)$ vrhunski šport, $(F)$ turizem in $(G)$ raziskovanje. Za vsako predstavljeno postavko so se udeleženci opredelili na petstopenjski Likertovi 
Preglednica 4 Opisna statistika ocen želja študentov dodiplomskega programa kineziologije za umestitev na področja delovnih okolij

\begin{tabular}{|c|c|c|c|c|c|c|c|c|c|}
\hline \multirow[t]{2}{*}{ Področja } & \multirow[t]{2}{*}{ Min } & \multirow[t]{2}{*}{ Max } & \multirow[t]{2}{*}{ Me } & \multirow[t]{2}{*}{ AS } & \multirow[t]{2}{*}{ SO } & \multicolumn{2}{|c|}{ Koef. asim. } & \multicolumn{2}{|c|}{ Koef. splošč. } \\
\hline & & & & & & Stat. & SE & Stat. & SE \\
\hline (A) & 1,00 & 5,00 & 4 & 4,0 & 1,085 & $-0,925$ & 0,279 & 0,109 & 0,552 \\
\hline (B) & 1,00 & 5,00 & 3 & 2,73 & 1,272 & 0,078 & 0,281 & $-1,207$ & 0,555 \\
\hline (C) & 1,00 & 5,00 & 4 & 3,46 & 1,100 & $-0,750$ & 0,279 & 0,031 & 0,552 \\
\hline (Č) & 1,00 & 5,00 & 3 & 3,16 & 1,194 & $-0,024$ & 0,279 & $-0,877$ & 0,552 \\
\hline (D) & 2,00 & 5,00 & 4 & 4,08 & 0,812 & $-0,473$ & 0,281 & $-0,497$ & 0,555 \\
\hline (E) & 1,00 & 5,00 & 4 & 3,88 & 1,414 & $-1,035$ & 0,279 & $-0,324$ & 0,552 \\
\hline (F) & 1,00 & 5,00 & 4 & 3,53 & 1,149 & $-0,596$ & 0,279 & $-0,348$ & 0,552 \\
\hline (G) & 1,00 & 5,00 & 4 & 3,47 & 1,326 & $-0,393$ & 0,279 & $-1,014$ & 0,552 \\
\hline
\end{tabular}

Opombe Min - najnižji sumarni dosežek, Max - najvišji sumarni dosežek, Me - mediana, AS - aritmetična sredina, SO - standardni odklon, SE - standardna napaka. Področja: (A) krepitev zdravja, (B) organiziranost in administracija $v$ športu, (C) obšolske in prostočasne dejavnosti v vzgoji in izobraževanju, (Č) varovanje zdravja na delovnem mestu, (D) rekreativni šport, (E) vrhunski šport, (F) turizem, (G) raziskovanje.

lestvici strinjanja, pri čemer je 1 pomenila »sploh se ne strinjam«, 5 pa »popolnoma se strinjam« (preglednica 4).

Skladno z namenom študije smo želeli ugotoviti, katera delovna okolja in področja dela so za študente kineziologije najbolj zaželena. Preglednica 4 predstavlja opisno statistiko za ocene želja študentov kineziologije o umestitvi na področja delovnih okolij. Udeleženci so v povprečju izkazali najvišjo stopnjo strinjanja $s$ trditvijo, ki opisuje njihovo željo po delu na področju rekreativnega športa $(A S=4,08 ; S O=0,812)$, po povprečnih ocenah temu sledita delo na področju krepitve zdravja $(A S=4,0 ; S O=1,085)$ ter vrhunskega športa $(A S=3,88 ; S O=1,414)$. $V$ najmanjši meri so se udeleženci strinjali, da bi si želeli delati na področju organizacije in administracije $v$ športu $(A S=2,73 ; S O=$ $1,272)$. Naši rezultati se večinoma ujemajo z rezultati študije, ki je bila predhodno opravljena z uporabo enakega vprašalnika (Plevnik and Babnik 2020).

Naslednje raziskovalno vprašanje, ki smo si ga zastavili in ga preverili s Kruskal-Wallisovim $\mathrm{H}$-statističnim preizkusom, je, ali se želje o umestitvi na delovno področje razlikujejo glede na obstoječe delovne izkušnje. Ugotovili smo, da se študentje glede na obstoječe delovne izkušnje ne razlikujejo v željah po umestitvi v določena delovna okolja, se pa glede na raven gibalne aktivnosti razlikujejo v želji za delo na področju $(F)$ turizma $(H=12,088, p=0,002)$ ter mejno na področju (A) krepitve zdravja $(H=5,968, p=0,051)$. Za umestitev na obe delovni področji največjo željo izraža skupina najmanj/nizko gibalno aktivnih študentov. 
Preglednica 5 Ocena strinjanja za delo z različno starostno oz. ciljno skupino

\begin{tabular}{lrrrrr}
\hline Starostna oz. ciljna skupina & $(1)$ & $(2)$ & $(3)$ & $(4)$ & $(5)$ \\
\hline Otroci in mladostniki & 1,4 & 6,8 & 17,6 & 39,2 & 35,1 \\
Delovno aktivna populacija & 1,4 & 4,1 & 18,9 & 45,9 & 29,7 \\
Starejši & 8,1 & 17,6 & 21,6 & 33,8 & 18,9 \\
Delo s posamezniki & & & 9,0 & 31,1 & 59,5 \\
Delo s skupino & & 8,1 & 18,9 & 41,9 & 31,1 \\
Zdrave osebe & 6,8 & 24,3 & 29,7 & 27,0 & 12,2 \\
Osebe s posebnimi potrebami/invalidi & 14,9 & 18,9 & 29,7 & 23,0 & 13,5 \\
Osebe s prisotnimi dej. tveg. za zdravje in KNB & 4,1 & 18,9 & 23 & 33,8 & 20,3 \\
\hline
\end{tabular}

Opombe (1) sploh se ne strinjam, (2) delno se strinjam, (3) sem neodločen, (4) delno se strinjam, (5) popolnoma se strinjam. $V$ odstotkih.

V nadaljevanju predstavljamo rezultate ocen strinjanja študentov za posamezne značilnosti umeščanja v delovno okolje po zaključku študija. Najprej nas je zanimala želja študentov za delo s posameznimi starostnimi skupinami prebivalcev. Ugotavljamo, da največji delež študentov izraža interes za delo s populacijo otrok in mladostnikov, ki ji sledita populaciji delovno aktivnih posameznikov in starejših (preglednica 5). Izraziteje študentje izražajo željo za delo s posamezniki ter ciljno skupino oseb s prisotnimi dejavniki tveganja za zdravje oz. KNB. Rezultati nakazujejo trende. $S \chi^{2}$-statističnim preizkusom hipoteze neodvisnosti smo preverili razlike med ocenami glede na letnik študija; statistično značilnih razlik nismo ugotovili pri nobeni izmed ocen želja.

$\checkmark$ nadaljevanju nas je zanimala želja študentov glede oblike zaposlitve po zaključku dodiplomskega študija. V največjem deležu navajajo neodločenost tako glede oblike zaposlitve kot tudi glede nadaljevanja študija na podiplomski magistrski stopnji. S $\chi^{2}$-statističnim preizkusom hipoteze neodvisnosti smo preverili razlike med trditvami glede na letnik študija. Statistično značilnih razlik nismo ugotovili pri nobeni izmed trditev v preglednici 6.

Zanimala nas je tudi želja študentov po uporabi vsebin in opravil stro-

Preglednica 6 Želja po zaključku dodiplomskega študija

\begin{tabular}{lrrrrr}
\hline Izražena želja po zaključku dodiplomskega študija & $(1)$ & $(2)$ & $(3)$ & (4) & (5) \\
\hline Iskanje stalne zap. preko drugega delodajalca & 9,6 & 8,2 & 31,5 & 28,8 & 21,9 \\
Samozaposlitev & 1,4 & 5,4 & 33,8 & 28,4 & 31,1 \\
Nad. študija na magistrski stopnji kineziologije & 9,5 & 4,1 & 41,9 & 14,9 & 29,7 \\
Nad. študija na drugih magistrskih programih & 18,9 & 12,2 & 40,5 & 18,9 & 9,5 \\
\hline
\end{tabular}

Opombe (1) sploh se ne strinjam, (2) delno se strinjam, (3) sem neodločen, (4) delno se strinjam, (5) popolnoma se strinjam. $V$ odstotkih. 
Preglednica 7 Uporaba vsebin in opravil strokovnega področja po prehodu v delovno okolje

\begin{tabular}{lrrrrr}
\hline Uporaba vsebine & (1) & (2) & (3) & (4) & (5) \\
\hline $\begin{array}{l}\text { Želja po uporabi znanj načrtovanja, organiziranja, } \\
\text { izvajanja in analize gibalne/športne vadbe }\end{array}$ & & 5,4 & 32,4 & 62,2 \\
Želja uporaba diagnostike gibalnega statusa & 2,7 & 2,7 & 10,8 & 37,8 & 45,9 \\
\hline
\end{tabular}

Opombe (1) sploh se ne strinjam, (2) delno se strinjam, (3) sem neodločen, (4) delno se strinjam, (5) popolnoma se strinjam. V odstotkih.

kovnega področja pri bodočem poklicnem delu. Študentje izražajo večjo željo po uporabi znanj načrtovanja, organiziranja, izvajanja in analize gibalne/športne vadbe, manj pa po uporabi znanj in opravil diagnostike gibalnega statusa. $\mathrm{S} \chi^{2}$-statističnim preizkusom hipoteze neodvisnosti smo preverili razlike med trditvami glede na letnik študija. Statistično značilnih razlik nismo ugotovili pri nobeni izmed trditev v preglednici 7.

Naloga nosilcev in izvajalcev študijskih programov je poleg izvedbe študijskega programa tudi redna skrb za umeščanje diplomantov $v$ delovno okolje. $Z$ ustreznim pregledom in s spremljanjem trendov na strokovnem področju lahko s primernimi usmeritvami, predvsem pa s prilagajanjem študijskih in obštudijskih vsebin študente seznanijo s potrebami delovnih okolij (Ryan 2015). Omenjena naloga je posebno pomembna pri novih študijskih programih in novih poklicnih profilih, kamor sodita tudi strokovno področje kineziologije in strokovni profil kineziologa (Melton in Dail 2017). Čeprav številni mednarodni in nacionalni dokumenti (MacCallum, Howson in Gopu 2012; Hallal idr. 2012; Zelaznik in Harper 2007; Dwyer idr. 2020; Bauman idr. 2012; Grabara, Nawrocka in Powerska-Didkowska 2017; World Health Organization 2018; Warburton in Bredin 2017; Gill idr. 2013) potrjujejo pomen vsebin in potreb po strokovnjakih s področij načrtovanja, organiziranja, izvajanja in vrednotenja gibalnih/športnih aktivnosti, je skrb za njihovo umeščanje v delovna okolja še vedno nezaključen proces.

Ugotovitve naše študije kažejo, da se želja študentov po umestitvi v delovna okolja in vsebinska področja (šport, krepitev zdravja itd.) po zaključku dodiplomskega izobraževanja ujema tako $z$ nacionalnimi kot tudi mednarodnimi smernicami in priporočili. To ugotovitev ocenjujemo kot izredno pomembno, saj kaže na dejstvo, da se potrebe po profilu strokovnjakov s področja kineziologije ujemajo z željami za delo bodočih strokovnjakov. Rezultati kažejo, da želi velika večina študentov pri bodočem delu uporabiti praktična znanja vodenja (načrtovanje, organiziranje, izvajanje in analiza) procesa gibalne/športne vadbe, kar lahko razumemo kot željo po poklicnem delu v 
praktičnih okoljih pri delu z različnimi ciljnimi in starostnimi skupinami, tako pri individualnem delu kot pri delu v skupinah. Več naporov bi veljalo usmeriti v promocijo dela s starostno skupino starejših prebivalcev, saj projekcije staranja kažejo na povečevanje deleža starejših v starostni strukturi prebivalcev v prihodnjem obdobju. Menimo, da so nadaljnje študije možnosti umeščanja in zaposlovanja ter sledenje stanju zaposlitev kineziologov nujni za prihodnji razvoj delovnih okolij za kineziologe. Številne že navedene raziskave navajajo zaskrbljujoče podatke o posledicah zniževanja gibalnih zmogljivosti splošne populacije. Omenjenim ugotovitvam morajo slediti tudi študije, ki sistematično preučujejo zaposlitev in delo kineziologov na področju spodbujanja aktivnega življenjskega sloga in vodenja gibalnih/športnih programov s ciljem razvoja in ohranjanja splošne gibalne zmogljivosti in krepitve zdravja različnih starostnih ter ciljnih skupin prebivalcev.

\section{Zaključek}

V prispevku predstavljamo mnenje študentov kineziologije o pomenu študijskih in obštudijskih vsebin za uspešen prehod v delovno okolje. Študentje kot najpomembnejšo ocenjujejo posamično trditev »poznavanja in usvojenosti vsebin obveznih predmetov s področno strokovnimi vsebinami«, kot najpomembnejši faktor pa »dopolnilne študijske vsebine«, pri čemer največji delež variance pojasni faktor »vseživljenjsko učenje«. Ugotovili smo, da študentje največji interes za umestitev $v$ delovno okolje po zaključku študija izražajo za področja rekreativnega športa, krepitve zdravja in vrhunskega športa. Glede dela s posameznimi skupinami največjo željo izražajo za delo s starostno skupino otrok in mladostnikov, $v$ obliki individualnega pristopa ter s ciljno skupino oseb, ki ima že izražene dejavnike tveganja za zdravje. Kljub temu da so učinki rednih gibalnih aktivnosti umeščeni v številne mednarodne in nacionalne dokumente ter prepoznani kot pomemben dejavnik javnega zdravja oz. pozitivnih učinkov na zdravje posameznikov in celotne družbe, je tudi naloga nosilcev in izvajalcev študijskih programov, da vplivajo na uspešen prehod mladih diplomantov $v$ delovna okolja.

\section{Literatura}

Backović Juričan, A. 2020. »Delovanje zdravstvenovzgojnih centrov in centrov za krepitev zdravja na področju telesne dejavnosti v lokalnih skupnostih." V Izzivi športnih organizacij na področju športne rekreacije, turizma in okolja: 15. kongres Športa za vse; zbornik prispevkov, ur. M. Pajek, 88-94. Ljubljana: Olimpijski komite Slovenije in Združenje športnih zvez.

Bauman, A. E., R. S. Reis, J. F. Sallis, J. C. Wells, R. J. F. Loos in B. W. Martin. 2012. »Correlates of Physical Activity." The Lancet 380 (9838): 258-271. 
Bodary, P. F., in M. Gross. 2018. »Innovative Teaching and Learning Strategies in Kinesiology."Kinesiology Review 7 (4): 321-327.

Child, D. 2006. The Essentials of Factor Analysis. 3. izd. London in New York: Continuum.

Dwyer, M. J., M. Pasini, S. De Dominicis in E. Righi. 2020. »Physical Activity: Benefits and Challenges during the COVID-19 Pandemic."Scandinavian Journal of Medicine and Science in Sports 30 (7): 1291-1294.

Ennis, C. D. 2010. »New Directions in Undergraduate and Graduate Education in Kinesiology and Physical Education." Quest 62 (1): 76-91.

Fakulteta za vede o zdravju. B. I. »Aplikativna Kineziologija: študijski program 1. stopnje.« https://fvz.upr.si/studij/aplikativna-kineziologija-un/.

Gill, D. L., C. C. Hammond, E. J. Reifsteck, C. M. Jehu, R. A. Williams, M. M. Adams, E. H. Lange, K. Becofsky, E. Rodriguez in Y. T. Shang. 2013. »Physical Activity and Quality of Life." Journal of Preventive Medicine and Public Health 46 (priloga 1): S28-S34.

Grabara, M., A. Nawrocka in A. Powerska-Didkowska. 2017. »The Relationship between Physical Activity and Work Ability: A Cross-Sectional Study of Teachers. « International Journal of Occupational Medicine and Environmental Health 31 (1): 1-9.

Hallal, P. C., A. E. Bauman, G. W. Heath, H. W. Kohl, I. M. Lee in M. Pratt. 2012. »Physical Activity: More of the Same Is Not Enough.»The Lancet 380 (9838): 190-191.

Hoffman, S. J., in D. V. Knudson, ur. 2018. Introduction to Kinesiology: Studying Physical Activity. 5. izd. Champaign, IL: Human Kinetics.

Jakovljević, M., T. Knific in M. Petrič. 2017. Testiranje telesne pripravljenosti odraslih oseb: priročnik za preiskovalce. Ljubljana: Nacionalni inštitut za javno zdravje.

Kleva, M. 2017. »Report from the 2nd Round Table 'A Kinesiologist in the Labour Market.'« Annales Kinesiologiae 8 (1): 51-52.

MacCallum, L., N. Howson in N. Gopu. 2012. Designed to Move: A Physical Activity Action Agenda. American College of Sports Medicine, Nike in International Council of Sport Science and Physical Education.

Melton, D., in K. D. Teresa. 2017. „Classroom to Community: Field Studies for Exercise Science Students.« Journal of Physical Education, Recreation \& Dance 88 (6): 21-25.

Melton, B., A. Hansen in J. Gross. 2010. »Trends in Physical Activity Interest in the College and University Setting. « College Student Journal 44 (3): 785-789.

Nacionalni inštitut za javno zdravje. 2016. Preventivni program za otroke in mladostnike: prepoznava in obravnava čezmerne hranjenosti in debelosti. Ur. P. Kotnik in S. Dravec. Ljubljana: Nacionalni inštitut za javno zdravje.

—. 2020. Zdravstvenovzgojni centri/Centri za krepitev zdravja. Ljubljana: Nacionalni inštitut za javno zdravje. 
Piercy, K. L., R. P. Troiano, R. M. Ballard, S. A. Carlson, J. E. Fulton, D. A. Galuska, S. M. George in R. D. Olson 2018. »The Physical Activity Guidelines for Americans. " JAMA - The Journal of the American Medical Association 320 (19). https://doi.org/10.1001/jama.2018.14854.

Plevnik, M., in K. Babnik. 2020. »Učni stili in preference za opravljanje bodočega poklicnega dela študentov in študentk dodiplomskega študija kineziologije.« Revija za elementarno izobraževanje/Journal of Elementary Education 13 (posebna št): 81-104.

Plevnik, M., in R. Pišot. 2016. »Report from the Round Table 'A Kinesiologist in the Labour Market.'« Annales Kinesiologiae 7 (2): 175-180.

Prskalo, I., M. Badrić in D. Tomić. 2019. »Kinesiology and Sustainable Future.» Croatian Journal of Education/Hrvatski časopis za odgoj i obrazovanje 21 (posebna št. 1): 213-223.

Resolucija o nacionalnem programu o prehrani in telesni dejavnosti za zdravje 2015-2025 (ReNPPTDZ). 2015. Uradni list Republike Slovenije, št. 58. https:// www.uradni-list.si/1/objava.jsp?sop=2015-01-2441.

Resolucija o nacionalnem programu športa v Republiki Sloveniji za obdobje 2014-2023 (ReNPŠ14-23). 2014. Uradni list Republike Slovenije, št. 26. https:// www.uradni-list.si/1/objava.jsp?sop=2014-01-1071.

Ryan, T. 2015. „Quality Assurance in Higher Education: A Review of Literature.» Higher Learning Research Communications 5 (4): 1-12.

Strel, J., G. Mišič, J. Strel in T. Glažar, ur. 2016. Telesna zmogljivost za boljše zdravje in počutje: vloga osnovnega zdravstva in lokalne skupnosti pri zagotavljanju ustrezne telesne zmogljivosti po vrhniškem modelu. Logatec: Fitlab.

Warburton, D. E. R., in S. S. D. Bredin. 2017. »Health Benefits of Physical Activity: A Systematic Review of Current Systematic Reviews." Current Opinion in Cardiology 32 (5): 541-556.

World Health Organization. 2018. Global Action Plan on Physical Activity 20182030: More Active People for Healthier World. Ženeva: World Health Organization.

Zakon o športu (ZŠpo-1). 2017. Uradni list Republike Slovenije, št. 29. https:// www.uradni-list.si/1/objava.jsp?sop=2017-01-1523.

Zakon o varstvu in zdravju pri delu (ZVZD-1). 2011. Uradni list Republike Slovenije, št. 43. https://www.uradni-list.si/1/objava.jsp?sop=2011-01-2039.

Zelaznik, H. N., in W. A. Harper. 2007. "Skill and Physical Activity: A Central Dogma for Kinesiology.« Quest 59 (1): 163-169.

\section{Students' Opinion on the Importance of Curricular Contents for the Successful Transition to the Work Environment for Future Kinesiologists}

Concern for the successful transition of graduate students into the work environment is also one of the responsibilities of faculties and holders of study programmes. The questionnaire was used to investigate the importance of study 
forms, contents and study-related activities for the transition to the work environment and the students' desire for placement in professional fields among 78 undergraduate kinesiology students. The collected data were evaluated using descriptive statistics. The dimensional structure was analysed using factor analysis. The participants evaluated the 'knowledge and mastery of the content of compulsory subjects with subject-specific content' $(M=4.68, S D=0.55)$ as the most important single statement and 'supplementary study content' ( $M$ $=4.36, S D=0.66$ ) as the most important factor. The factor 'lifelong learning' explained the largest proportion of variance (37.27\%). We found that students express the greatest interest in working in the work environment after graduation in the areas of recreational sports $(M=4.08 ; S D=0.81)$, in the area of health preservation $(M=4.0 ; S D=1.09)$ and in the area of elite sports $(M=3.88 ; S D=$ 1.41). The results of the study show the wishes of the kinesiology students for the fields of work after completion of their education. At the same time, results provide their assessment of the importance of various curricular contents for a successful transition into the work environment.

Keywords: environment, kinesiologist, exercise, sports, health 